\title{
Association of Circadian Clock and Severe Acute Respiratory Syndrome Coronavirus 2 Infection
}

\author{
Renu Tomar' and Alok Raghav \\ ${ }^{1}$ School of Public Health, Poornima University, Jaipur, India \\ ${ }^{2}$ Multidisciplinary Research Unit, MoHFW, GSVM Medical College, Kanpur, India
}

\begin{abstract}
Severe acute respiratory syndrome coronavirus 2 (SARS-CoV-2) is causing devastation worldwide accounting millions of deaths. This virus is among the new member of the Coronaviridae family with differences from SARS-CoV. The entry of the virus to human cells mediated through spike (S) proteins with angiotensin-converting enzyme 2 (ACE2). Several comorbidities such as hypertension, diabetes, HIV, malignancy, diabetes, chronic respiratory disease, and cardiovascular disease makes a person susceptible to COVID-19 infection. Circadian rhythm/oscillations or biological clock plays important role in the pathogenesis of SARS-CoV-2 infection mediated through ACE2 and BMAL1.

Key Words: Severe acute respiratory syndrome coronavirus 2; Hypertension; Diabetes mellitus; Circadian rhythm; Oscillations

Received: May 5, 2021 Revised: June 6, 2021 Accepted: June 7, 2021

Corresponding author: Renu Tomar, MPH, School of Public Health, Poornima University, Plot No. IS-2027-2031, Ramchandrapura P.O. Vidhani, Vatika Rd, Sitapura, Jaipur, Rajasthan 303905, India.

Tel: 91-9412672185, Fax: 91-5712741863, E-mail: renutomar345@gmail.com

@ This is an Open Access article distributed under the terms of the Creative Commons Attribution Non-Commercial License (https://creativecommons.org/licenses/bync/4.0) which permits unrestricted non-commercial use, distribution, and reproduction in any medium, provided the original work is properly cited.
\end{abstract}

\section{INTRODUCTION}

Severe acute respiratory syndrome coronavirus 2 (SARS-CoV-2) belongs to the family of Coronaviridae and has similar properties like SARS-CoV and Middle East respiratory syndrome coronavirus (MERS-CoV) [1]. The primary host is believed to be a bat as the genome sequence of SARS-CoV2 has high complementarity $(90 \%)$ with bat coronavirus while the intermediate host between bat and human was most probably a Himalayan civet [2]. The first clustered cases of COVID-19 were reported on 31 December 2019 in people associated with the wet market in Wuhan, China where live or slaughtered animals were sold [3]. On 11th March 2020, WHO declared this as pandemic disease. From the first day of its occurrence, it took less than 3 months to cross the figure of 500,000 cases worldwide [4]. This tremendous spread of this disease is mainly because of its high sustainability on nonliving things, i.e., for more than 72 hours. Currently, there are $153,094,318$ confirmed cases with 3,206,339 confirmed deaths from 197 countries. The mean period of occurrence of symptoms is 5.5 days and it may be possible that a high number of undiag- nosed cases without any symptoms will be there who are spreading the disease unknowingly $[5,6]$. Some studies have projected a high number of cases which can create serious havoc [7]. Currently, the most affected part of the world in the current scenario is USA \& European provinces with the maximum number of deaths reported from Italy (15,362 deaths) [8] and Spain (11,774 deaths) [9].

\section{PATHOGENESIS OF SARS-CoV-2 INFECTION}

The disease spreads through the mucous and faecal medium [10-12]. It has similar pathogenic action as that of SARS-CoV $[13,14]$. The virus comprises two types of spike protein (S protein) all over its membrane which helps it in binding with the host cell $[15,16]$, an envelope protein (E protein) and membrane protein (M protein) form the capsid of the virus. Single-stranded positive RNA is the genetic material of this virus [17].

SARS-CoV2 also uses angiotensin-converting enzyme 2 (ACE2) receptors of type 2 cells of alveoli like SARS-CoV for interaction 
with host cells. Transmembrane protease serine 2 (TMPRSS2) is needed for S protein priming [13]. There are two types of S protein, i.e., S1 and S2 which participate in binding and fusion, respectively. S1 binds with the ACE2 receptor while S2 mediates fusion between virus and host cell [18]. Once the virus enters the host cell, it shreds its protein part and RNA is released into the cytoplasm. The ssRNA(+) uses host mechanism to translate into two polypeptides, i.e., $\mathrm{PPa} 1$ and $\mathrm{PP} 1 \mathrm{ab}$ which form a replication transcription complex. Further, the formed complex uses RNA dependent RNA polymerase to replicate and make multiple copies. Finally, it gets assembled into its virion vesicles and fuses with plasma membrane and gets released. It spreads down the bronchial tubes and starts infecting neighbor cells. The accumulated proteins of virus, dead type 2 cells of alveoli attract macrophages and cytokines as an immune response and result in inflammation. This further results in the filling of lungs with water and dead cells causing acute respiratory disease [19-21].

\section{MORBIDITIES IN SARS-CoV-2 INFECTION}

SARS-CoV-2 is known worldwide pandemic infect people of all age groups; however, persons above the age of 60 years with comorbidities like hypertension, diabetes, HIV, malignancy, diabetes, chronic respiratory disease, and cardiovascular disease (CVD) are more susceptible to infection [22]. People having diabetes mellitus (DM) are susceptible for getting COVID-19 infection due to their impaired phagocytic cell characteristics. In one of the recently published study, it was found that DM people have significantly high levels of ACE2 receptors, this might prejudice people with DM to SARS-CoV-2 infection [23]. Recently collected data showed that $11-58 \%$ with COVID-19 infection have DM with $8 \%$ fatality rate $[24,25]$.

\section{Obesity}

Obesity (body mass index $>30 \mathrm{~kg} / \mathrm{m}^{2}$ ) is associated with low oxygen saturation of blood as suggested by the recently published study [26]. Obesity is among the mild associated comorbidities in COVID-19 infections. Previously published literature showed that $47.6 \%$ obese people showed SARS-CoV-2 infection among them $68.6 \%$ was on ventilators because of critical conditions [26]. Thus, it is proposed that BMI is a risk factor for COVID-19 severity.

\section{Chronic obstructive pulmonary disease}

COVID-19 severity is also found to be associated with the chronic obstructive pulmonary disease (COPD). In previously published study, COPD and other chronic disorders were found to linked with SARS (1.4\%) and MERS (13\%) [27]. It has been observed that around $50-52.3 \%$ subjects of COPD admitted to intensive care unit (ICU) having COVID-19, this is because of the microenvironment changes in lungs, blockage of air passages due to increase in mucous secretion [28].

\section{Asthma}

It is observed that patients with asthma shows delayed innate antiviral immune response due to impaired secretion of interferon (IFN)- $\lambda$. In previously published study, SARS and MERS affected population of $1.4 \%$ and $13 \%$ respectively showed association with asthma [27]. It is believed that asthma could be the major risk factor for the SARS-CoV-2 infection. In one of the previously published study, it was found that asthma is not associated with COVID-19 disease; however, asthmatic smokers showed direct association with SARS-CoV-2 infection [29].

\section{Hypertension}

Hypertension is a potent risk factor in various diseases. Uncontrolled blood pressure is found to be associated with COVID-19 and high case fatality rate (CFR). In one of the recently published Chinese study, it was found that $23 \%$ hypertensive subjects showed $6 \%$ CFR [30]. The pathophysiology of this association is linked with ACE2 inhibitors. In the treatment of hypertension, the ACE2 inhibitors and angiotensin receptor blockers are frequently used targets for the treatment. Moreover, elevated amount of these inhibitors, upregulate the expression of ACE2 receptors, thereby putting on high risk for SARS-CoV-2 infection [31]. The management of hypertension is essential part in COVID-19 patients that might also be helpful in reducing the disease burden and morbidity.

\section{CVDs}

CVDs is strongly associated with SARS and MERS infection. In one of the previously published study, CVDs showed $8 \%$ and $30 \%$ significant association in SARS and MERS patients, respectively $[32,33]$. In another study, it was found that $17 \%$ of the COVID-19 non-survivors had CVDs [34]. However, the mechanism underlying such morbidities is not known, but most of the COVID-19 patients with CVDs reported compromised immune system [24]. In another research, it was found that increased levels of inflammatory cytokines in COVID-19 is a potent risk factor for development of atherosclerosis, pro-coagulant initiation, and hemodynamic instability that is responsible for ischemia and thrombosis [35].

Moreover, some of the other potential risk factors associated with co-morbidities in COVID-19 patients includes, HIV, malignancies, liver diseases, and other immune system related disorders. Management of the SARS-CoV-2 infected subjects should focus on treatment of all comorbidities related to COVID-19 disease.

\section{ROLE OF CIRCADIAN RHYTHM IN PATHOGENESIS OF SARS-CoV-2 INFECTION}

Circadian rhythm or biological clock plays important role in the pathogenesis of SARS-CoV-2 infection. In COVID-19, ACE2 plays anti-inflammatory role upon hydrolysis of angiotensin 2 into angiotensin 1-7. In one of the recently published study conducted one older individuals, which are at higher risk of COVID-19 de- 
velopment, it was found that there is significantly lower levels of ACE2 and angiotensin 1-7 levels [36]. SARS-CoV and SARSCoV-2 have strong similarity as evident by both in-vitro and invivo studies that is dependent on the ACE2 recognition, that serve as the entry point for the virus. Several studies demonstrated that circulating renin-angiotensin system showed circadian rhythmicity [37,38]. In one of the study, it was concluded that ACE2 expression followed circadian pattern and it has been stated by the authors that time of day of viral encounter may significantly influence the COVID-19 entry and replication mechanism [39]. Viral clearance within the body exhibit circadian oscillations as concluded by recently published study [40].

Hypoxemic respiratory failure is major cause of death in $\mathrm{CO}$ VID-19 that involves circadian rhythm and molecular biology of gene expressions involved in it. It is evident that cellular oxygenation actively influence the circadian clocks by the process mediated through hypoxia inducible factor 1 alpha [40]. In another study, alteration in the circadian clock regulated gene expression causes respiratory failure in COVID-19 particularly in lungs thereby causing acute lung injuries [41]. SARS-CoV-2 infection causes expression of the cytokines involving transcription of the cytokines encoding genes that causes stimulation of cytokines release in time-of-day regulation. It is evident that clock proteins and clock genes activate and suppress several cytokines [42]. In another study suppression of type 1 IFN responses were observed in mechanically ventilated COVID-19 patient [43]. SARS-CoV-2 infection is affected by the patient's circadian clock system through two mechanism 1) by direct viral replication within the host's cells and 2) by indirect effects on innate and adaptive immune responses. In one of the previously published study, it was found that BMAL1 have direct effect on circadian oscillations in mouse herpes virus infection [44]. It was concluded by the authors that circadian clock machinery is regulating the angiotensin mechanisms especially ACE2 that is correlated with the SARS-CoV-2 infection [45].

Circadian clock also have strong association with delirium. It was found that about 30\% ICU admitted COVID-19 patients have increased risk of developing delirium due to direct central nervous system (CNS) invasion, CNS mediated inflammatory responses and other factors [46]. In basic research it was evident that circadian clock and delirium infection have strong association [46].

\section{CONCLUSION}

Considering the several aspects of COVID-19 infections, circadian oscillations and biological clocks have strong association. The factors such as obesity, asthma, hypertension, CVDs poses threat to COVID-19 patients causing significant morbidities in SARS-CoV-2 infected patients. Circadian clock proteins and genes play vital role in regulation of pathogenesis behind the COVID-19 infection. However, limited attention on circadian rhythmicity and biological clock in COVID-19 patients causing delay in recover- ies and posing threat towards mortality of these infected patients. Focusing of the circadian clock, may helpful in reduction of the severity of the COVID-19 infection and knowledge of state of circadian proteins and genes may be used to mitigate the COVID-19 severity.

\section{Acknowledgments}

None

\section{Conflicts of Interest}

The author AR is thankful to Department of Health Research, Ministry of Health and Family Welfare, New Delhi for providing financial assistance in the form of salary.

\section{Author Contributions}

Conceptualization: Alok Raghav. Data curation: all authors. Formal analysis: all authors. Investigation: all authors. Methodology: all authors. Project administration: Alok Raghav. Resources: all authors. Software: all authors. Supervision: Alok Raghav. Validation: Alok Raghav. Visualization: Renu Tomar. Writing-original draft: Renu Tomar. Writing_review \& editing: Alok Raghav.

\section{ORCID iDs}

Renu Tomar (D)

https://orcid.org/0000-0002-5760-2673

Alok Raghav (iD

https://orcid.org/0000-0002-2161-0604

\section{REFERENCES}

1. Rothan HA, Byrareddy SN. The epidemiology and pathogenesis of coronavirus disease (COVID-19) outbreak. J Autoimmun 2020;109:102433.

2. Woo PC, Lau SK, Chu CM, Chan KH, Tsoi HW, Huang Y, et al. Characterization and complete genome sequence of a novel coronavirus, coronavirus HKU1, from patients with pneumonia. J Virol 2005;79:884-895.

3. Guo YR, Cao QD, Hong ZS, Tan YY, Chen SD, Jin HJ, et al. The origin, transmission and clinical therapies on coronavirus disease 2019 (COVID-19) outbreak - an update on the status. Mil Med Res 2020;7:11.

4. Hoffmann M, Kleine-Weber H, Schroeder S, Krüger N, Herrler T, Erichsen S, et al. SARS-CoV-2 Cell Entry Depends on ACE2 and TMPRSS2 and Is Blocked by a Clinically Proven Protease Inhibitor. Cell 2020;181:271-280.

5. World Health Organization. WHO coronavirus (COVID-19) dashboard. Available at: https://covid19.who.int/. Accessed May 4, 2021.

6. Goh GK, Dunker AK, Foster JA, Uversky VN. Rigidity of the outer shell predicted by a protein intrinsic disorder model sheds light on the COVID-19 (Wuhan-2019-nCoV) infectivity. Biomolecules 2020;10:331.

7. Liu Y, Gayle AA, Wilder-Smith A, Rocklöv J. The reproductive number of COVID-19 is higher compared to SARS coronavirus. J Travel Med 2020;27: taaa021.

8. Hoseinpour Dehkordi A, Alizadeh M, Derakhshan P, Babazadeh P, Jahandideh A. Understanding epidemic data and statistics: a case study of COVID-19. J Med Virol 2020;92:868-882.

9. Fahmi I. \#COVID19 coronavirus disease 2019. Available at: https://pers. droneemprit.id/covid19/. Accessed May 4, 2021.

10. Li Q, Guan X, Wu P, Wang X, Zhou L, Tong Y, et al. Early transmission dynamics in Wuhan, China, of novel coronavirus-infected pneumonia. N Engl J Med 2020;382:1199-1207.

11. Zhang W, Du RH, Li B, Zheng XS, Yang XL, Hu B, et al. Molecular and serological investigation of 2019-nCoV infected patients: implication of multiple shedding routes. Emerg Microbes Infect 2020;9:386-389.

12. Lee PI, Hsueh PR. Emerging threats from zoonotic coronaviruses-from 
SARS and MERS to 2019-nCoV. J Microbiol Immunol Infect 2020;53:365367.

13. Hoffmann M, Kleine-Weber H, Krüger N, Müller M, Drosten C, Pöhlmann S. The novel coronavirus 2019 (2019-nCoV) uses the SARS-coronavirus receptor ACE2 and the cellular protease TMPRSS2 for entry into target cells. BioRxiv 2020 [preprint]. Available at: https://www.biorxiv.org/content/10.1 101/2020.01.31.929042v1.abstract.

14. Tortorici MA, Veesler D. Structural insights into coronavirus entry. Adv Virus Res 2019;105:93-116.

15. Thiel V, Siddell SG. Reverse genetics of coronaviruses using vaccinia virus vectors. In: Enjuanes L, editor. Coronavirus replication and reverse genetics. Berlin: Springer, 2005, p. 199-227.

16. Yu F, Du L, Ojcius DM, Pan C, Jiang S. Measures for diagnosing and treating infections by a novel coronavirus responsible for a pneumonia outbreak originating in Wuhan, China. Microbes Infect 2020;22:74-79.

17. Cui J, Li F, Shi ZL. Origin and evolution of pathogenic coronaviruses. Nat Rev Microbiol 2019;17:181-192.

18. Raghav A, Khan ZA, Upadhayay VK, Tripathi P, Gautam KA, Mishra BK, et al. Mesenchymal stem cell-derived exosomes exhibit promising potential for treating SARS-CoV-2-infected patients. Cells 2021;10:587.

19. de Wilde AH, Snijder EJ, Kikkert M, van Hemert MJ. Host factors in coronavirus replication. In: Tripp RA, Tompkins SM, editors. Roles of host gene and non-coding RNA expression in virus infection. Cham: Springer, 2017, p. 1-42.

20. Sawicki SG, Sawicki DL. Coronavirus transcription: a perspective. Curr Top Microbiol Immunol 2005;287:31-55.

21. Perrier A, Bonnin A, Desmarets L, Danneels A, Goffard A, Rouillé Y, et al. The C-terminal domain of the MERS coronavirus M protein contains a trans-Golgi network localization signal. J Biol Chem 2019;294:14406-14421.

22. World Health Organization. Coronavirus disease (COVID-19): situation report - 141. Available at: https://www.who.int/docs/default-source/coronaviruse/situation-reports/20200609-covid-19-sitrep-141. pdf?sfvrsn=72fa1b16_2. Accessed May 4, 2021.

23. Rao S, Lau A, So HC. Exploring diseases/traits and blood proteins causally related to expression of ACE2, the putative receptor of SARS-CoV-2: a Mendelian randomization analysis highlights tentative relevance of diabetes-related traits. Diabetes Care 2020;43:1416-1426.

24. Yang J, Zheng Y, Gou X, Pu K, Chen Z, Guo Q, et al. Prevalence of comorbidities and its effects in patients infected with SARS-CoV-2: a systematic review and meta-analysis. Int J Infect Dis 2020;94:91-95.

25. Bhatraju PK, Ghassemieh BJ, Nichols M, Kim R, Jerome KR, Nalla AK, et al. Critically ill patients in the Seattle region-case series. N Engl J Med 2020;382: 2012-2022.

26. Ejaz H, Alsrhani A, Zafar A, Javed H, Junaid K, Abdalla AE, et al. COVID-19 and comorbidities: deleterious impact on infected patients. J Infect Public Health 2020;13:1833-1839.

27. Yin Y, Wunderink RG. MERS, SARS and other coronaviruses as causes of pneumonia. Respirology 2018;23:130-137.

28. Liu W, Tao ZW, Wang L, Yuan ML, Liu K, Zhou L, et al. Analysis of factors associated with disease outcomes in hospitalized patients with 2019 novel coronavirus disease. Chin Med J (Engl) 2020;133:1032-1038.

29. Zhao Q, Meng M, Kumar R, Wu Y, Huang J, Lian N, et al. The impact of COPD and smoking history on the severity of COVID-19: a systemic review and meta-analysis. J Med Virol 2020;92:1915-1921.

30. Ma LY, Chen WW, Gao RL, Liu LS, Zhu ML, Wang YJ, et al. China cardiovascular diseases report 2018: an updated summary. J Geriatr Cardiol 2020; 17:1-8.

31. Fang L, Karakiulakis G, Roth M. Are patients with hypertension and diabetes mellitus at increased risk for COVID-19 infection? Lancet Respir Med 2020;8:e21.

32. Chan JW, Ng CK, Chan YH, Mok TY, Lee S, Chu SY, et al. Short term outcome and risk factors for adverse clinical outcomes in adults with severe acute respiratory syndrome (SARS). Thorax 2003;58:686-689.

33. Badawi A, Ryoo SG. Prevalence of comorbidities in the Middle East respiratory syndrome coronavirus (MERS-CoV): a systematic review and metaanalysis. Int J Infect Dis 2016;49:129-133.

34. Zheng YY, Ma YT, Zhang JY, Xie X. COVID-19 and the cardiovascular system. Nat Rev Cardiol 2020;17:259-260.

35. Bonow RO, Fonarow GC, O'Gara PT, Yancy CW. Association of coronavirus disease 2019 (COVID-19) with myocardial injury and mortality. JAMA Cardiol 2020;5:751-753.

36. AlGhatrif M, Cingolani O, Lakatta EG. The dilemma of coronavirus disease 2019, aging, and cardiovascular disease: insights from cardiovascular aging science. JAMA Cardiol 2020;5:747-748.

37. Cugini P, Lucia P. Circadian rhythm of the renin-angiotensin-aldosterone system: a summary of our research studies. Clin Ter 2004;155:287-291.

38. Herichová I, Mravec B, Stebelová K, Krizanová O, Jurkovicová D, Kvetnanský R, et al. Rhythmic clock gene expression in heart, kidney and some brain nuclei involved in blood pressure control in hypertensive TGR(mREN-2)27 rats. Mol Cell Biochem 2007;296:25-34.

39. Bakhtazad A, Jafari R, Khaksari M, Khastar H, Salehi M, Jafarisani M, et al. Paying attention to circadian rhythms in the treatment of COVID-19. Basic and Clinical Neuroscience 2020;11:233-246.

40. Haspel J, Kim M, Zee P, Schwarzmeier T, Montagnese S, Panda S, et al. A timely call to arms: COVID-19, the circadian clock, and critical care. J Biol Rhythms 2021;36:55-70.

41. Numminen $H$, Syrjälä M, Benthin G, Kaste M, Hillbom M. The effect of acute ingestion of a large dose of alcohol on the hemostatic system and its circadian variation. Stroke 2000;31:1269-1273.

42. Timmons GA, O'Siorain JR, Kennedy OD, Curtis AM, Early JO. Innate rhythms: clocks at the center of monocyte and macrophage function. Front Immunol 2020;11:1743.

43. Hadjadj J, Yatim N, Barnabei L, Corneau A, Boussier J, Smith N, et al. Impaired type I interferon activity and inflammatory responses in severe $\mathrm{CO}$ VID-19 patients. Science 2020;369:718-724.

44. Edgar RS, Stangherlin A, Nagy AD, Nicoll MP, Efstathiou S, O’Neill JS, et al. Cell autonomous regulation of herpes and influenza virus infection by the circadian clock. Proc Natl Acad Sci U S A 2016;113:10085-10090.

45. Herichova I, Zsoldosova K, Vesela A, Zeman M. Effect of angiotensin II infusion on rhythmic clock gene expression and local renin-angiotensin system in the aorta of Wistar rats. Endocr Regul 2014;48:144-151.

46. Kotfis K, Williams Roberson S, Wilson JE, Dabrowski W, Pun BT, Ely EW. COVID-19: ICU delirium management during SARS-CoV-2 pandemic. Crit Care 2020;24:176. 